\title{
Memória e esquecimento na mídia contemporânea: Fernando em Pessoa de Laerte
}

\author{
Luciano Barbosa Justino \\ Universidade Estadual da Paraíba (João Pessoa, Brasil)
}

\begin{abstract}
RESUMO: ESTE ENSAIO TOMA COMO CORPUS DE ANÁLISE A HQ O POETA, DE LAERTE, COM O OBJETIVO DE ENTENDER A MEMÓRIA, À LUZ DA SEMIÓTICA DA CULTURA E DO CONCEITO DE HISTÓRIA COMO CONSTELAÇÃO DE TEMPOS DE WALTER BENJAMIN, COMO UM DISCURSO QUE CRUZA O PRESENTE COM OUTRAS TEMPORALIDADES NÃO CONTEMPORÂNEAS. POSTULA-SE AQUI QUE A NARRATIVA DE LAERTE UTILIZA OS VERSOS E A PERSONA DE FERNANDO PESSOA E SUA MIGRAÇÃO PARA A TV PARA MOSTRAR A PERTINÊNCIA DA POESIA ENQUANTO MEMÓRIA VIVA NO PROPALADO PÓS-MODERNISMO E EM SUAS FORMAS SÓCIO-DISCURSIVAS.
\end{abstract}

ABSTRACT: THIS PAPER TAKES AS CORPUS OF ANALYSIS THE COMIC BOOK O POETA BY LAERTE, WITH THE OBJECTIVE OF UNDERSTANDING THE MEMORY, IN THE LIGHT OF THE SEMIOTICS OF THE CULTURE AND OF THE CONCEPT OF HISTORY AS CONSTELLATION OF TIMES BY WALTER BENJAMIN, AS A DISCOURSE THAT CROSSES THE PRESENT WITH TEMPORALITIES OTHER THAN THE CONTEMPORARY.

PALAVRAS-CHAVE: HISTÓRIA EM QUADRINHOS, MÍDIA CONTEMPORÂNEA, POESIA, MEMÓRIA.

KEYWORDS: POETRY, SEMIOTIC, MEMORY, COMICS. 
poeta" (1994, p. 41-53) é uma HQ de Laerte cujo enredo é o périplo do poeta "Fernando em Pessoa" declamando seus versos e saindo ileso das diversas tentativas empreendidas pelos "Piratas do Tietê" de destruí-lo, ao fim do qual o poeta, depois de ter sua imagem transmitida pela TV, lidera uma invasão da cidade por poetas solitários libertados. Tenho aqui um duplo objetivo: 1) Analisar, à luz da semiótica da cultura e do conceito de história de Walter Benjamin, como o inusitado duelo entre o poeta, o Poeta, e os anti-heróis do Tietê revela um instigante diálogo entre diversas redes de circulação discursiva que sugerem uma semiose da memória à luz de uma leitura radicalmente contemporânea da tradição literária e cultural luso-brasileira; 2) Demonstrar como alguns “objetos” da chamada indústria cultural, Cinema, TV, HQ, Jogos digitais, estão em condições, creio que como nenhum outro na mesma proporção, de propor abordagens críticas das relações ininterruptas tanto de nossas tradições quanto do movimento próprio do nosso presente. Dado o locus fronteiriço de tais "objetos", em uma palavra intercultural, cujo caráter fluido e disseminante, rizomático, para falar com Deleuze e Guattari, não é ancilar, será preciso metodologias processuais, rítmicas, capazes de apreender sua troca de lugares e sua inevitável conectividade com outros "agenciamentos coletivos de enunciação", tais como o cinema, a TV e, no caso da HQ de Laerte, também a literatura.

Em "O poeta", a poesia carrega uma densa bagagem, um saber de outra temporalidade que insiste em permanecer vivo na lógica simbólica do audiovisual e da cidade contemporânea. Fernando Pessoa, metonímia do poeta por excelência, contrasta com o dinamismo alucinante e fragmentador dos automóveis. Seus versos flutuam, "atemporais", acima dos insultos que vêm de piratas, pedestres e motoristas. Os versos do poeta, assim como seu carro velho, estruturam-se numa sintaxe singular, um tanto anacrônica, mas que flui, atravessa, percorre os espaços urbanos da metrópole, parece que pela força mesma de sua não contemporaneidade. Todas as tentativas de assassinato empreendidas pelos piratas e corroboradas pela intenção do próprio poeta em dar cabo a sua vida, garrucha, canhão, querosene, espada, são insuficientes. O poeta não esquece e não se deixa esquecer. Ironicamente, é de sua ancestralidade que tira a seiva que a mantém viva para o homem de hoje, a despeito da ameaça de todas as mortes, sobretudo, as da TV. Contudo, não obstante sua durabilidade, ela não fica imune à interferência do cotidiano, da contingência histórica de nossos modos 
de vida, que têm na televisão sua mídia mais representativa. Da constelação de tempos, passa-se ao trânsito entre midiasferas: da voz e do vídeo, tudo isto contado "no quadro" da história em quadrinho.

\section{I}

A semiótica parte da hipótese básica de que toda relação humana é mediada através de processos semiósicos. Ela dirá que a HQ de Laerte não pode ser lida como signo ou forma, mas como devir, pois nela não existem os signos isoladamente, existem redes de produção discursivas. Uma indústria, de frangos, de brinquedos ou de "cultura", uma indústria cultural, nunca é um objeto isolado, mímesis da hegemonia capitalista e de suas formações discursivas dominantes. Uma indústria implica sempre alteridades, zonas simbólicas e assignificantes, máquinas desejantes. Nas palavras de Landowski (2002, p. IX), "a única coisa que poderia nos estar presente é o sentido, nunca estamos presentes na insignificância". No signo, estar presente é estar em relação, "é o princípio do primado epistemológico da relação sobre os termos que está na base do procedimento semiótico", é reconhecimento de diferenças e disseminação (LANDOWSKI, 2002, p. 3). Em A memória na mídia, a evolução dos memes de afeto, Mônica Rebecca Ferrari Nunes (2001, p. 56), trata a relação signo, modo de vida, memória a partir do processo gene, princípio elementar dos "corpos biológicos", meme, unidade mínima da transmissão cultural. Articulando a noção de Mimeme de Dawkins e a de Semiosfera de Iuri Lotman e Ivan Bystrina, a autora propõe que é na relação entre memes e genes que se forma, segundo ela, uma "união biossimbólica":

O semioticista da cultura Ivan Brystina descreve o funcionamento da cultura a partir da intersecção de três níveis de codificação: códigos hipolinguais ou primários (código genético, informação bioquímica, etc.), linguais ou secundários (produzindo textos cujos objetivos é atingir fins instrumentais, técnicos e cotidianos, e texto racionais, como os textos lógicos e matemáticos) e hiperlinguais ou terciários (códigos culturais organizando textos criativo-imaginativos). Ainda que a teoria de Bystrina expresse uma aparente separação entre natureza/cultura/ técnica, em nenhum momento estes campos sobrevivem isoladamente. Códigos primários, secundários e terciários se entretecem (NUNES, 2001, p. 60). 
Os três níveis de codificação a que se refere Bystrina e retomados por Mônica Nunes possuem analogia com as três categorias cognitivas básicas de Charles Sanders Peirce e que constituem os três fundamentos do signo: suas propriedades (primeiridade), a relação que o signo estabelece com o seu objeto (secundidade) e os horizontes de expectativa que condiciona a interpretação, a entidade lógica que Peirce chamou de interpretante. Para melhor compreender os movimentos de sentido que a HQ de Laerte faz circular, a semiosfera faz das três matrizes biossimbólicas engendramentos sonoros, visuais e verbais.

O som está, por hipótese, mais próximo de um grau zero da semiose como pura substância aquém de qualquer configuração linguageira, um primeiro que só existe em relação a um segundo que ele antecede. A imagem já é um segundo, já aponta para um fora; a semiose visual indica algo que o antecede por princípio lógico. O signo verbal não constitui simplesmente uma linguagem, mas uma metalinguagem, um sistema modelizante, capaz de refletir sobre todos os outros, só a verbalidade é capaz de comentário e dissertação. A tríade semiótica se constitui, assim, no processo que vai do suporte e de suas modalidades sígnicas, atravessa as relações do sujeito com seu meio ambiente imediato e alcança as formações discursivas que presidem o imaginário e a ideologia. Na HQ de Laerte o espaço da memória se dá no cruzamento entre uma temporalidade da escrita, representada por "Fernando em Pessoa", e a dominante cultural contemporânea da televisão e do vídeo. O trânsito de diversas midiasferas posto em cena pel" "O poeta" nos ajuda a compreender que o estatuto da memória enquanto semiose é o diálogo, sempre arriscado, entre a duração que é sempre imagem situada num tempo e num espaço outro e o instante de sua construção cognitiva cuja intensidade é proporcional ao ritmo videal do esquecimento, princípio elementar da semiose televisiva dominante. Tentaremos aprofundar esta questão mais adiante, inclusive invertendo-a. A pertinência da noção de intersemiose para o estudo da memória entendida como codificação provisória de uma multiplicidade em processo, pode ser lida ainda nestas palavras de Lotman e Uspenskii:

O gênero humano começou a ligar a sua própria existência à existência de uma memória não-hereditária que se alargava constantemente. $\mathrm{E}$ isso exigia a contínua atualização do sistema codificante, que tem sempre que estar presente, quer 
na consciência do destinatário quer na do remetente, como um sistema desautomatizado. A exigência duma constante auto-renovação, de coversão em outro, conservando-se, embora, ele próprio, constitui um dos mecanismos fundamentais de funcionamento da cultura (LOTMAN \& USPENSKI, 2003, p. 38).

Walter Benjamin (1994, p. 222-232) pensou a história como um "objeto cujo lugar não é o tempo homogêneo e vazio, mas um tempo saturado de 'agoras"'. O conceito benjamineano de história aponta para um conflito entre uma história hegemônica, o historicismo dos vencedores, e uma história soterrada, frágil, perdida, mas ainda pulsante, inserida numa multiplicidade viva, passível de reminiscência. Em oposição à uniformização posta em marcha pela modernidade e por seu contra-exemplo hediondo, o nazismo, defende uma história da multiplicidade e da diferença, da função política da oralidade enquanto espaço de reminiscência e luta por uma outra memória, por uma temporalidade não contemporânea viva. Retornaremos à questão da oralidade mais adiante para tratar da relação literatura/cidade/TV na HQ de Laerte. Por ora nos interessa, para unir a semiótica, que supõe sempre relações triádicas, a uma leitura da memória à luz de uma concepção de história plural, pensá-la diferentemente da história historicista por sua capacidade de assegurar permanências (PINTO, 1998, p. 292), o que implica dizer que, enquanto espaço de apreensão crítica das diversas temporalidades do agora, ela deve estar em constante tensão e diálogo com os modos de vida contemporâneos e os gêneros do discurso que lhes codifica, em "O poeta”, poesia, literatura, televisão.

\section{II}

Parto da hipótese de que a literatura, como nós a entendemos nos últimos dois séculos, não é anterior à modernidade, a poesia ao certo é mais antiga, ela é do tempo em que o logos antecedia a luz e em cuja força esta bebia sua existência, para lembrar a metáfora do Gênesis judaico-cristão. Logo, poesia e literatura não se confundem enquanto formações discursivas. Não obstante terem caminhado juntas na modernidade, devido à funcionalidade do livro e da escrita fonética, vêm de agenciamentos semiósicos diferentes, usam, se pensarmos em largos períodos históricos, suportes diferentes e forma diver- 
sas de interação sócio-dircursivas. Se aqui se parte do pressuposto de que memória é processo semiósico, poesia e literatura diferem, sobretudo, enquanto formas da memória. Contudo, a cultura do livro uniu de tal modo as duas que hoje é quase impossível separá-las. "O poeta" faz cruzar estas duas temporalidades da poesia, enquanto literatura, que é para nós a poesia na modernidade, e enquanto gênero ligado à oralidade e às funções fáticas da voz. Sobre a relação da literatura com a modernidade, Michel Foucault (2001, p. 139) afirmou que será pensá-la como uma formação discursiva da modernidade, cuja relação com os clássicos só a nós, sujeitos desta mesma modernidade, diz respeito. Tal distinção é fundamental para entendermos a passagem que vai da poesia literária de "Fernando em Pessoa" à poesia urbana dos poetas contemporâneos que invadem a cidade a partir da televisão na HQ de Laerte. Senão vejamos:

A sequência protagonizada por Fernando em Pessoa é feita de quadros sobriamente subjetivos. Sóbrios porque o enquandramento do personagem no centro dos quadros dá regularidade e diminui o dinamismo. Subjetivos porque o tédio e a melancolia dos versos "rimam" com os enquadramentos em planos próximos do poeta, atraídos pela personalidade da persona. No sexto quadro, paradigmático da primeira sequência, um interlocutor-intruso, um motorista apressado, grita: - "Ô viaaado!"; enquanto isso, o poeta fala para a imensidão do "mar do Tietê". Duas modalidades de fala, a solene e mais antiga, guardada de toda contaminação, flutuando no espaço prosaico da cidade e de seus automóveis. A segunda, do cotidiano vulgar pós-moderno. Duas falas remetem a duas velocidades e dois posicionamentos dos homens e dos objetos no meio ambiente, dois modos de vida e duas temporalidades. O quadro pode ser dividido em duas partes que formam duas lógicas simbólicas: de um lado, "Fernando em Pessoa", seu automóvel antigo, sua postura sobre um púlpito ou um palco, de costas pro movimento do real, sua roupa, sua própria presença; do outro, os ruídos, a rapidez dos traços, o automóvel de design contemporâneo, as onomatopéias, a fala sem persona.

Os sons que saem da boca do personagem são enormemente discursivos. A fala pessoana ressoa uma memória cuja unidade descarta a cidade contemporânea e seu ritmo desumanizador. Fala escritural, literária, no sentido forte do termo. Noutra direção, os sons da aceleração e da linguagem da fala comum cotidiana trazem todas as características daquilo que anteriormente 

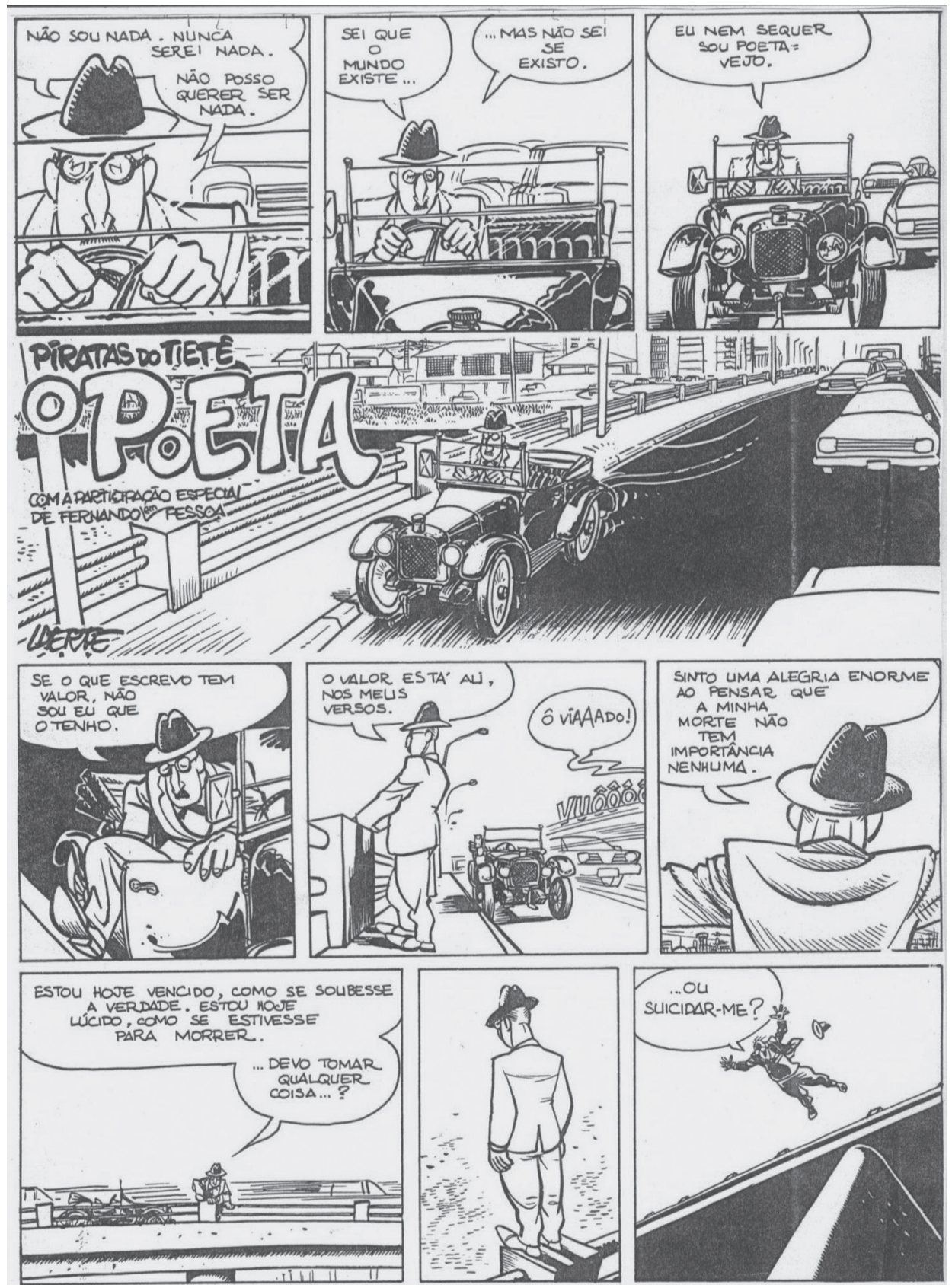

(Fig. 1) 
se disse sobre a primeiridade como acaso, liberdade e imediaticidade, anterior, podemos dizer, avesso, a toda reminiscência. Se Fernando em Pessoa é fortemente marcado pela discursividade; as onomatopéias e os traços rápidos são sonoros e assignificantes, metonímias do esquecimento. Sobre este aspecto, os versos do poeta carregam a tradição, enquanto o ritmo das onomatopéias representa a fragilidade da memória poética diante da ritmia, outra, da metrópole. A poesia que Fernando em Pessoa traz como representante máximo e exemplar é esta poesia tratada como unicidade e autonomia em oposição às formas híbridas e supostamente vulgarizadoras da cultura de massa. Voltaremos a isto mais adiante.

Abrindo o foco para apreender o imagético da imagem, ainda no sexto quadro, de um lado, tem-se um espaço estático e sóbrio, onde predominam as linhas retas e a simetria estabelecida pela figura humana no primeiro plano. No extremo oposto, tem-se o predomínio de linhas curvas e quebradas. Cada espaço do quadro configura uma imago particular. A abordagem detida do desenho mostra uma imagem dividida entre as características da terceiridade, as formas em toda parte do quadro onde predomina a figura do poeta, e a primeiridade, onde sobressai o automóvel em alta velocidade. Aqui, a semiótica nos ensina que mesmo a imagem, um sistema semiótico de segundo grau, pode assumir características tanto da sonoridade quanto da semiose verbal. Se a poesia como personificada em Fernando em Pessoa reforça a "unicidade da memória", os automóveis e o espaço da cidade contemporânea a colocam em perigo. Para seguirmos este caminho, embora tenhamos que sair dele mais adiante, é útil lembrar que o espaço da cidade para o poeta moderno, Baudelaire e Sousândrade foram dos primeiros a sabê-lo, era problemático na medida em que quebrava toda relação pacífica entre o discurso e a natureza que o romantismo havia imaginado. O tema da cidade desumanizadora e não poética, "mosaico de esquecimentos", reforça o esoterismo do discurso poético em relação à cidade contemporânea, que nada mais é que o "anacronismo" da memória num espaço de fragmentação e esvaziamento. $\mathrm{O}$ mergulho de Fernando em Pessoa no rio-mar do Tietê acaba por ser um mergulho suicida nesta temporalidade esvaziada das relações de sociabilidade. Mas, "alienado" de tudo em volta estará o poeta da literatura interessado em socializar-se? Aqui a HQ assume um paradoxo criativo, pois é justamente a memória que o poeta traz que o obriga à socialização e à permanência, a despeito de seu 
projeto suicida, na medida em que só há permanência no partilhável. Contudo, essa permanência socializadora da memória se dá exatamente pela hibridização, pelo mergulho mesmo, no espaço fragmentário e vazio da cidade, a começar por suas formas simbólicas predominantes, o kitsch e a televisão. A seriedade dessa "antiguidade antiga", a poesia, personificada no seu poeta maior, torna-se kitsch no instante em que a HQ desfaz a fronteira entre a arte e a vida, a memória e o cotidiano no primeiro quadro da sequência seguinte, quando o poeta cai no mar numa posição no mínimo prosaica.

De pernas para o ar, num barco que em nada indica a potência retórica da sequência anterior, o poeta muda de idéia. Ao contrário do peso não dispersivo da tradição literária e da memória poética, agora o poeta vacila: a pancada na cabeça lhe dá um átimo de lucidez? O terceiro quadro reforça a postura anterior que ensaiava desconstruir-se; a densidade do discurso poético se reafirma pelo gesto solitário e sobre-humano: “vou existir! E-XIS-TIR!!”. Nos quinto e sexto quadros, o poeta, e seus versos, avançam num misto de fantasma e super-herói. A imponência obtida pela contra-plongée no sexto quadro contrasta com a pequenez e a fragilidade no plano aberto do quadro seguinte, diante da grandiosidade do barco dos piratas. A ironia, já anunciada no kitsch, assume ares de paródia, mas de uma paródia pasticheira, que incorpora o discurso outro como atualização crítica. Para lembrar Fredric Jameson (JAMESON, 1993, p. 28), na cidade contemporânea o pastiche supera a paródia por não ter o impulso satírico e risível. Ora, o riso é tão presente na narrativa de Laerte que a dicotomia jamesoneana só pode ter aplicabilidade se for redefinida. "O poeta" faz da migração da poesia para o espaço pós-moderno um pastiche paródico, que mantém a "mímica verbal" de outro tempo e lugar, no mesmo ato em que a ridiculariza, afirma e nega, preserva a poesia como temporalidade do descontínuo e a incorpora no atual. O efeito aqui não é de pura e simples incorporação, como é comum nas formas da cultura de massa contemporânea, objetos de análise de Jameson, mas de uma incorporação crítica, que conflui diferentes processos discursivos e diferentes modos de sociabilidade. Enquanto pastiche reafirma a força e a pertinência da memória poética; enquanto paródia critica seu anacronismo até o risível. Sob este aspecto, o encontro com os piratas é representativo: 

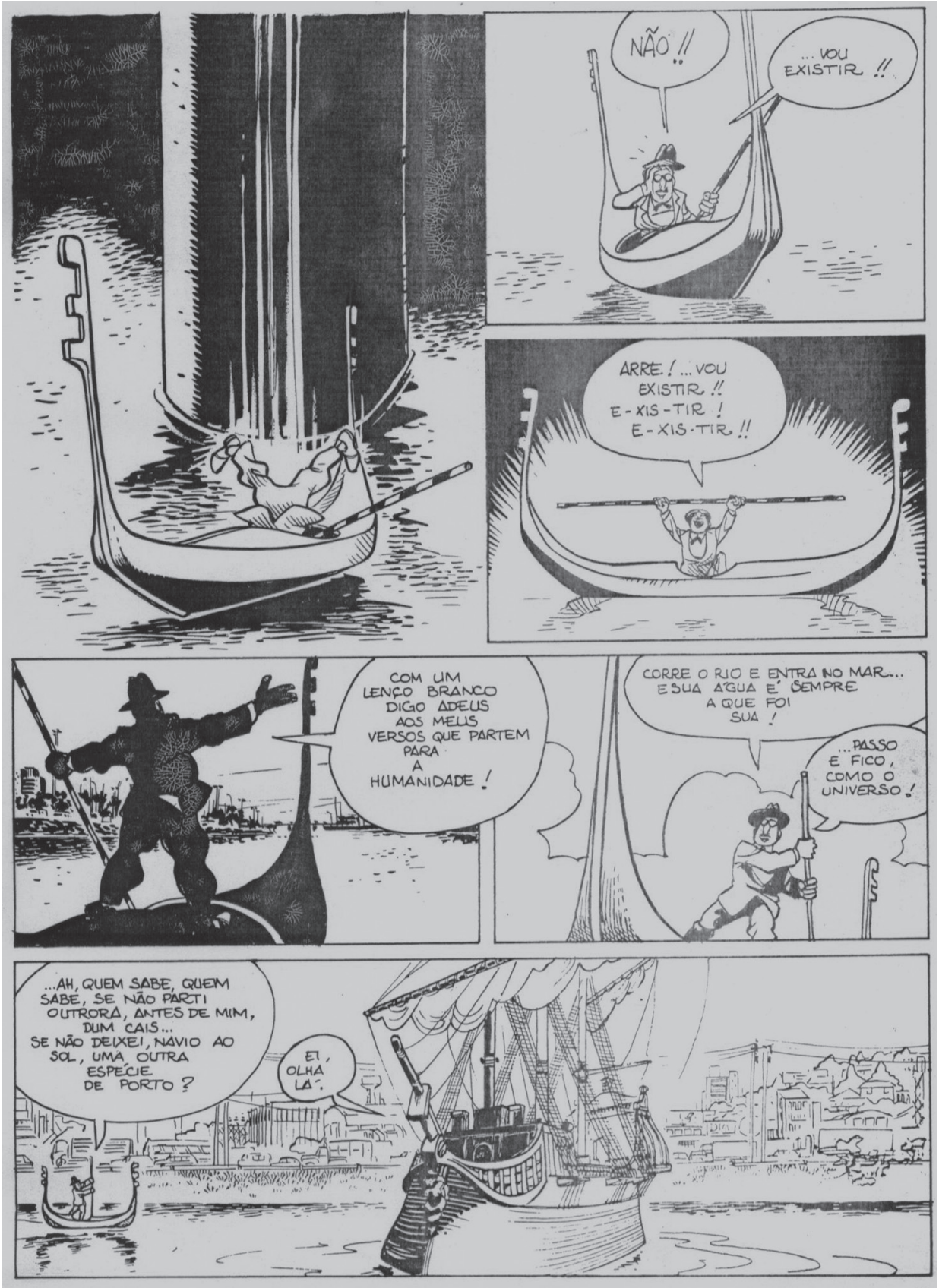

(Fig. 2) 

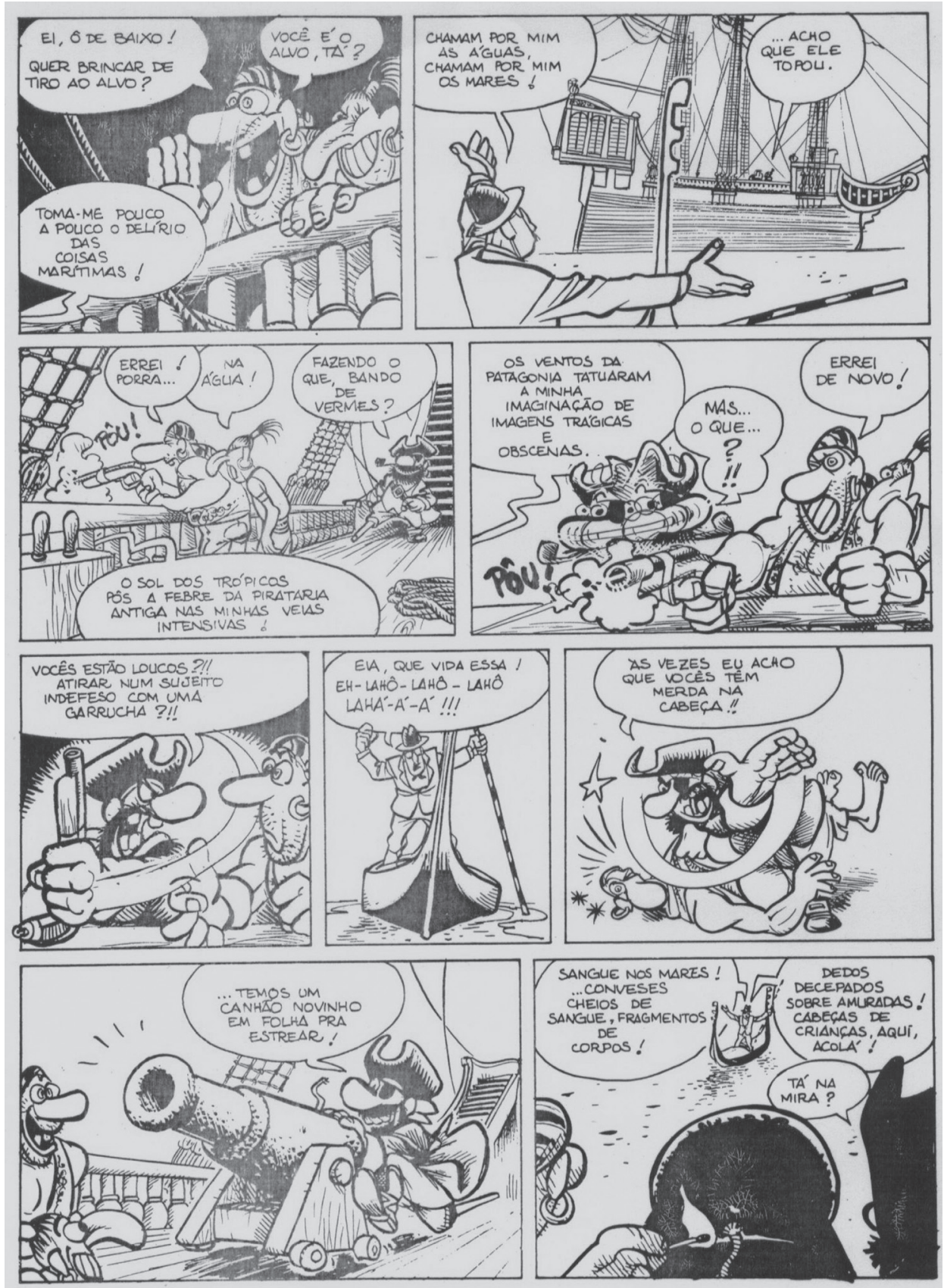

(Fig. 3) 
Os piratas, longe do discurso solene, destituídos de civilidade e de qualquer sentido de autoridade auto-instituída, aparecem como o outro sincrônico contemporâneo. Desdentados, violentos, sujos, críticos, caóticos, para-lógicos, abrem um riso satírico contra o anacronismo e a inutilidade da poesia em "tempos de vale tudo". Na sequência acima, "Fernando em Pessoa" aparece duas vezes: no belo e de sugestivo simbolismo português do segundo quadro e no sexto, em plena "Ode triunfal". Os piratas trazem o nonsense, a desconexão, a profunda perda da transcendência; estão atolados no aqui e agora, que se transforma para eles num presente eterno eternamente novo. No mundo dos piratas, toda lembrança é vã e inútil. O pirata até esquece que tem um canhão "pra estrear". Mergulhado na indicialidade primária do agora, não sabe (faria alguma diferença saber?) que o poeta carrega o largo arquivo. O poeta está para ele aquém de qualquer simbolismo; está surdo para o rumor.

Os piratas estão nos níveis da primeiridade, no sentimento sem reflexão do imediato, na extrema liberdade. Mas também estão nas formas da secundidade, pela atitude de reconhecimento da experiência do tempo e do espaço. Possuem uma compulsão pela ocorrência e pela ação sobre ela. O que os difere e os coloca como adversários de "Fernando em Pessoa" é seu não reconhecimento dos níveis da terceiridade, matriz de todos os contratos sociais, dos hábitos e, sobretudo, da memória. Quero crer que essa "des-memória assimbólica" é a matriz do riso. O pastiche aqui é em nada neutro, pelo contrário, ele apresenta-se em certo sentido mais radical que a paródia, porque ri dela mesma: os piratas quase afundam numa penúltima tentativa de eliminar o poeta. Tudo: o vocabulário, a fala coloquial-dialógica, o figurino, a natureza dos cortes, o dinamismo interno dos quadros, difere do cenário que acompanha "Fernando em Pessoa". Os cortes entre um quadro e outro eliminam as ações inúteis, dando rapidez e instantaneidade à sequência e ajudam a construir uma realidade de impacto e vibração. O dinamismo da cidade agora aparece com nitidez. Os automóveis da primeira sequência funcionam como antecipação do que o poeta vai encontrar. Lá, a aceleração envolve o poeta, que permanece quase imune a ela; nos piratas, ela avança sobre ele e intenta destruí-lo sem meias palavras ou metáforas metafóricas. Mas "Fernando em Pessoa", e seus versos, resistem. E sobrevivem. 


\section{III}
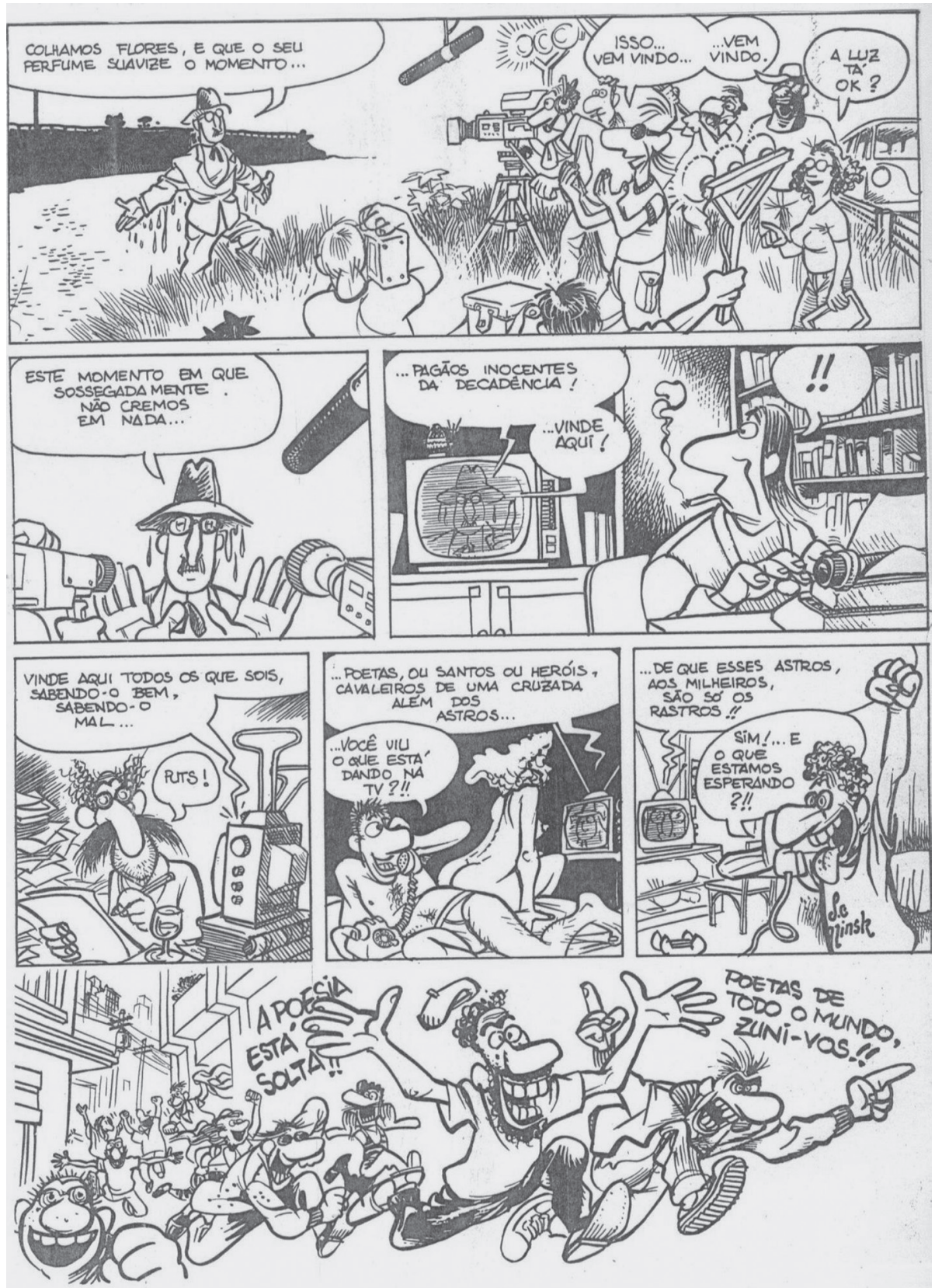

(Fig. 4) 
Saído ileso dos contínuos ataques e de todas as mortes que os piratas lançam sobre ele e seus versos, Fernando em Pessoa ressurge numa triunfal saída do mar do Tietê, mediado pelo aparato-televisão. É vítima de um novo ataque? Sim e não, pois é ele que avança sobre a TV, a natureza invasiva do vídeo é assaltada por ele que se transforma no mediador que reagrupa o laço social partido entre ele, poeta da literatura, e os outros, que agora podem ouvir de novo. Daí a voltarem a falar será um passo. É importante ressaltar aqui que, ao contrário de "Fernando em Pessoa" na primeira sequência, todos os poetas aparecem mediados pela TV e por outro dispositivo: TV e máquina de datilografia no terceiro quadro; TV e manuscrito no quarto e TV e telefone nos quinto e sexto, além dos suportes e agentes da própria TV nos dois primeiros. Fernando em Pessoa (será ele ainda?) convida: - "Pagãos inocentes da decadência! ... Vinde aqui!" (LAERTE, 1994, p. 51). Vinde para a poesia? Para o mar? Para a TV? Três vezes sim. Para o passado? Em que tempo se situa o poeta? Quais? A poesia é um espectro, ou desencadeia um, na audiência do dispositivo-TV? Claro está que um dispositivo genérico quando entra em contato com outro não abandona suas "origens", carrega-as com mais intensidade do que antes do contato. Mas ambos se reconfiguram. O meio mais novo e mais potente tende a agenciar o mais antigo e dar-lhe uma outra dinâmica, mas o mais antigo se vinga influenciando os hábitos de uso. As propriedades diferenciais do novo meio só vão ser exploradas depois que a memória for uma conquista da nova ferramenta. Assim, uns e outros acabam sendo simplesmente outros.

A montagem dos quadros nesta sequência é menos "simbolóide", menos mediada pela discursividade e pelo intelecto, como nos quadros da primeira sequência centralizados na gramática e na persona de "Fernando em Pessoa". Nem indicial, como nas sequências protagonizadas pelos piratas. À exceção do último quadro, nos demais os outros poetas e o próprio "Fernando em Pessoa" ficam no limbo, a TV os divide. O balão que indica o som que sai da TV curto-circuita o "tempo lógico" dos poetas das duas extremidades. O último quadro forma um silogismo: a memória, fragmentada pela aceleração da cidade e de suas máquinas de esquecimento, mantém-se viva ao ser capaz de continuar sendo sempre outra quando se abre pro diálogo. Fora dele, ela é folclore ou "patrimônio" ou, quando muito, lembrança individual. Lá, incapaz de manter viva a socialidade e a pertinência dos mortos, cá, solipsismo. 
Em “O poeta”, a memória não é só reviver, é, sobretudo, refazer. A poesia se liberta da literatura através de um meio fortemente sonoro. Ela faz assim uma espiral, toca e traz o passado, mas o expande a partir de sua contaminação pelo presente. A memória do uso é sempre maior que a da produção. Os que pensam numa suposta passividade da recepção, que o sentido último do meio de massa se esgota na intenção produtora, esquecem que o uso ultrapassa a intencionalidade na medida em que não separa os instrumentos e os modos de vida. Se o vídeo é a "dominante cultural" e "imprime a verdade secreta do nosso tempo", nas palavras de Fredric Jameson (1996, p. 91), se o seu cinetismo exclui a memória e a submete ao consumo (JAMESON, 1996, p. 94), em O poeta ela potencializa o despertar do passado. Walter Benjamin talvez tivesse gostado do pastiche paródico de Laerte, quando o que relampeja parece ser também o futuro do passado, representado aqui por um uso diferenciador da própria TV. Através dela, não só a memória poética sai da sombra, quanto sua própria historicidade, da televisão, se liberta do consumo a-crítico e clicherizado. Ela tira o escritor-poeta do espaço fechado e da cláusula, a cláusula que lá atrás imunizou "Fernando em Pessoa" e tira a própria TV do imobilismo.

\section{Referências Bibliográficas}

BENJAMIN, Walter. Sobre o conceito de história. In: Magia e técnica, arte e politica. Trad. Sérgio Paulo Rouanet. 7. ed. São Paulo: Brasiliense, 1994, p. 222-232.

FOUCAULT, Michel. Linguagem e literatura. In: MACHADO, Roberto. Foucault, a filosofia e a literatura. Rio de Janeiro: Jorge Zahar Ed., 2001, p. 137-174.

IVANOV, V. V. et al. Teses para uma análise semiótica da cultura. In: MACHADO, Irene. Escola de semiótica: a experiência de Tártu-Moscou para o estudo da cultura. São Paulo: Ateliê Editorial, 2003, p. 99-132.

JAMESON, Fredric. Vídeo: surrealismo sem inconsciente. In: Pós-modernismo: a lógica cultural do capitalismo tardio. São Paulo: Ática, 1996, 350 p.

JAMESON, Frederic. O pós-modernismo e a sociedade de consumo. In: KAPLAN, E. Ann (Org.). O mal estar no pós-moderno: teorias e práticas. Rio de Janeiro: Jorge Zahar Ed. 1993, p. 25-44.

LANDOWSKI, Eric. Presenças do outro: ensaios de sociossemiótica. São Paulo: Perspectiva, 2002. 
LAERTE. O poeta. In: . Os piratas do Tietê e outras barbaridades. São Paulo: Ensaio, 1994, p. 41-53.

LOTMAN, Iuri et al. Ensaios de semiótica russa. Lisboa: Horizonte, 1981. Apud MACHADO, Irene. Escola de semiótica: a experiência de Tártu-Moscou para o estudo da cultura. São Paulo: Ateliê Editorial, 2003, p. 99-132.

NUNES, Mônica Rebecca Ferrari. A memória na mídia: a evolução dos memes de afeto. São Paulo: Annablume, 2001.

PINTO, Júlio Pimentel. A poética da memória. In: Uma memória do mundo: ficção, memória e história em Jorge Luis Borges. São Paulo: Estação Liberdade, 1998, p. 283-322.

Recebido em 03 de maio e aprovado em 27 de maio de 2011. 